controls) or in the total number of days in hospital (IDUs: median 23, range 1-123; controls: median 27, range 2-217). Three of the IDUs claimed to be HIV positive at admission but were found to be HIV negative when tested: three others were known to be HIV negative and were admitted for treatment of injection site abscesses. Only one control patient was HIV negative: he had been admitted for source isolation at a time when his HIV status was unknown. Karnofsky scores were estimated for each patient at the time of admission, and used to calculate a mean score per patient ${ }^{1}$ : the scores were significantly higher in IDUs (IDUs: $58 \cdot 6$, SD 21.5 , controls: $46.5, \mathrm{SD} 14 \cdot 2, \mathrm{p}=0.005$ ), suggesting that they were less unwell. The IDUs had a total of 81 inpatient episodes, 29 of which were with an AIDS-defining illness (using the 1987 CDC criteria), compared with 90 inpatient episodes for controls, 65 of which were with an AIDS-defining illness $\chi^{2}$ $=21.4, p<0.001)$. All 13 IDUs who were on legal opiate prescriptions were prescribed methadone on the ward, as were seven of the 13 illegal opiate users.

Behavioural problems were recorded in the medical or nursing notes more often for IDUs than controls (16 incidents in 81 admissions for IDUs, four incidents in 90 admissions for controls, $\left.\chi^{2}=8 \cdot 2, p=0.04\right)$. Recorded incidents included use of non-prescribed drugs, serious non-compliance with treatment and physical or verbal aggression. The IDUs had more unplanned discharges than controls (17 out of 81 admissions vs four out of 90 admissions, $\chi^{2}=9 \cdot 3, p=0.002$ ). Amongst current IDUs, there was no difference in the number of recorded behavioural problems in those who were or were not prescribed methadone on the ward, or in those who were or were not receiving legal opiate prescriptions at the time of admission. However, behavioural problems were recorded more often in current opiate users compared with former users (15 incidents out of 60 admissions in current users vs 1 out of 21 in former users: $\chi^{2}=2 \cdot 8, \mathrm{p}=$ 0.037).

Substance misuse on the ward was documented in nine out of 81 admissions for IDUs: there were no recorded episodes in the control group $\left(\chi^{2}=8 \cdot 4, \quad \mathrm{p}=0.0009\right)$. Amongst current IDUs, there was no difference in episodes of substance misuse between those receiving methadone on the ward and those who were not, but there were fewer episodes in those receiving prescribed opiates at the time of admission (one incident in 27 admissions vs eight in $33, \chi^{2}=4.9, p=0.02$ ). No episodes were recorded in former IDUs.

Our data show no difference between IDUs and controls in the frequency or length of admissions: however, the IDUs were less unwell on admission. This may reflect poorer social circumstances (such as homelessness), inability to cope at home when unwell and difficulties complying with out-patient treatment, as was demonstrated by a study in France. ${ }^{2}$ Three IDUs were admitted to the unit by falsely claiming to be HIV positive, possibly because it may be easier for HIV positive IDUs to obtain opiates from medical services.

Drug users have a reputation for behaving badly during medical admissions, ${ }^{3}$ but we found relatively few recorded incidents, although they were more frequent in IDUs than controls. Interestingly, very few problems were noted in the group of former IDUs. Active drug users on HIV inpatient units are likely to need substantial psychosocial input. Nursing and medical staff may need training in dealing with difficult behaviour, and policies for prescription of replacement opiates may be helpful. To avoid unnecessary admission, outpatient HIV services need to be flexible and designed to accommodate drug users as well as non drug users. A liaison service, such as described by Orgel, ${ }^{4}$ provided by an addiction specialist could also improve care.

$$
\begin{array}{r}
\text { ALISON D GRANT* } \\
\text { EMILY JL FINCH† } \\
\text { CHARLOTTE FEINMANN† } \\
\text { ROB F MILLER } \\
\text { Department of Medicine* and } \\
\text { Department of Psychiatryt, } \\
\text { UCL Medical School, } \\
\text { Middlesex Hospital, } \\
\text { London WIN } 8 A A, U K
\end{array}
$$

Address for correspondence: Dr Emily JL Finch, Addiction Research Unit, National Addiction Centre, Addiction Sciences Building, 4 Windsor Walk, London SE5 $8 \mathrm{AF}$, UK.

1 Karnofsky DA, Burchenal JH. The clinical evaluation of chemotherapeutic agents against cancer. In: McLeod, CM (ed) Eeutic agents against cancer. In. McLeod, York, Columbia University Press, 1949.

York, Columbia University Press, 1949 . HIV infected patients to health care: a comparative (with non-IVDU) prospective study in Ile-de-France non-IVDU) prospective study in ine-de-France (abstract). Proceedings and Abstracts of IX Intermational
Conference on AIDS. Berlin, Germany; June 1993:PoB32-2274.

3 Lert F, Marne M-J. Hospital care for drug users with AIDS or HIV infection in France. AIDS Care 1992, 4:333-8.

4 Orgel MG. The role of a specialist in addiction (medical doctor) in liaison work with a department of HIV medicine (abstract). Proceedings and Abstracts of IX International Conference on AIDS. Berlin, Germany; June 1993:Po-D18-3938.

\section{Assessment of contraceptive choice in HIV seropositive women}

Condoms have proved impermeable in vitro to the human immunodeficiency virus (HIV) and when used consistently in HIV discordant couples have been associated with low seroconversion rates. ${ }^{23}$ They have been widely promoted as a means of reducing both HIV transmission and other sexually transmitted diseases whilst affording protection against an unwanted pregnancy. However, it is well recognised that there is a higher conception or failure rate with condoms than certain non barrier methods and fertility rates in HIV infected women are not significantly different from comparable non infected women. ${ }^{4}$ Little is known about the factors influencing HIV positive women to request contraceptives additional to condoms.

All HIV seropositive women attending our unit receive contraceptive counselling as part 
Partner's HIV status, parity, previous contraception and method chosen by the women

\begin{tabular}{|c|c|c|c|c|c|c|c|}
\hline \multirow[b]{2}{*}{$\begin{array}{l}\text { Patient } \\
\text { No }\end{array}$} & \multirow{2}{*}{$\begin{array}{l}\text { Partner's } \\
\text { HIV } \\
\text { status }\end{array}$} & \multirow[b]{2}{*}{ Parity } & \multicolumn{3}{|c|}{ Contraception } & \multicolumn{2}{|l|}{ Post FPC } \\
\hline & & & $\begin{array}{l}\text { Prior } \\
\text { to FPC }\end{array}$ & Outcome & At 1st FPC & $M C$ use & $\begin{array}{l}\text { Method } \\
\text { chosen }\end{array}$ \\
\hline 1 & $\begin{array}{l}\text { Positive } \\
\text { AIDS }\end{array}$ & 0 & $\begin{array}{l}\text { COCP } \\
\text { POP } \\
\text { D }\end{array}$ & $\begin{array}{l}\text { Satisfied } \\
\text { Nausea } \\
\text { Non compliant }\end{array}$ & MC & Yes & COCP \\
\hline 2 & Positive & $\begin{array}{l}1 \mathrm{C} \\
2 \mathrm{M} \\
1 \\
\text { TOP }\end{array}$ & $\begin{array}{l}\text { COCP } \\
\text { IP } \\
\text { IUCD }\end{array}$ & $\begin{array}{l}\text { Venous } \\
\text { thrombosis } \\
\text { Weight gain } \\
\text { Menorrhagia }\end{array}$ & MC & Yes & POP \\
\hline 3 & $\begin{array}{l}\text { Not } \\
\text { known }\end{array}$ & 2 TOP & COCP & $\begin{array}{l}\text { Breast } \\
\text { enlargement } \\
\text { Depression }\end{array}$ & MC & Yes & POP \\
\hline 4 & $\begin{array}{l}\text { Not } \\
\text { known }\end{array}$ & $1 \mathrm{C}$ & $\mathrm{COCP}$ & Irregular menses & MC & Yes & IP \\
\hline 5 & Positive & $1 \mathrm{C}$ & $\begin{array}{l}\text { COCP } \\
\text { POP }\end{array}$ & $\begin{array}{l}\text { Non compliant } \\
\text { Non compliant }\end{array}$ & $M$ & Yes & IP \\
\hline 6 & $\begin{array}{l}\text { Not } \\
\text { known }\end{array}$ & 0 & $\begin{array}{l}\text { COCP } \\
\text { POP }\end{array}$ & $\begin{array}{l}\text { Breast pain } \\
\text { Irregular menses } \\
\text { Mood swings }\end{array}$ & MC & Yes & IP \\
\hline 7 & $\begin{array}{l}\text { Not } \\
\text { known }\end{array}$ & $2 \mathrm{C}$ & MC & Non compliant & $\begin{array}{l}\text { Inconsistent } \\
\text { MC use }\end{array}$ & $\begin{array}{l}\text { Alternating } \\
\text { with FC }\end{array}$ & $\mathrm{FC} / \mathrm{MC}$ \\
\hline 8 & $\begin{array}{l}\text { Positive } \\
\text { AIDS }\end{array}$ & 1 TOP & $\mathrm{MC}$ & Non compliant & $\begin{array}{l}\text { Inconsistent } \\
\text { MC use }\end{array}$ & $\begin{array}{l}\text { Alternating } \\
\text { with FC }\end{array}$ & $\mathrm{FC} / \mathrm{MC}$ \\
\hline 9 & Positive & $\frac{1}{\text { TOP }}$ & $\begin{array}{l}\mathrm{MC} \\
\mathrm{COCP}\end{array}$ & $\begin{array}{l}\text { Usually compliant } \\
\text { but variable. } \\
\text { FC requested } \\
\text { Headaches }\end{array}$ & $\begin{array}{l}\text { Inconsistent } \\
\text { MC use }\end{array}$ & $\begin{array}{l}\text { Alternating } \\
\text { with FC }\end{array}$ & $\mathrm{FC} / \mathrm{MC}$ \\
\hline 10 & Positive & $1 \mathrm{TOP}$ & $\begin{array}{l}\text { IUCD } \\
\text { COCP } \\
\text { POP } \\
\text { IP } \\
\text { D }\end{array}$ & $\begin{array}{l}\text { Satisfied } \\
\text { Depression } \\
\text { Irregular menses } \\
\text { Bloating } \\
\text { Difficulty with } \\
\quad \text { insertion }\end{array}$ & IUCD & Yes & IUCD \\
\hline $\begin{array}{l}\text { IUCD } \\
\text { COCP } \\
\text { POP } \\
\text { IP } \\
{ }^{\star} \text { After }\end{array}$ & $\begin{array}{l}\text { - Intrauteri } \\
\text { - Combinec } \\
\text { - Progestog } \\
\text { - Injectable } \\
\text { IV diagnosi }\end{array}$ & $\begin{array}{l}\text { ontracep } \\
\text { al contra } \\
\text { only pill. } \\
\text { gestogen }\end{array}$ & $\begin{array}{l}\text { ice. } \\
\text { pill. }\end{array}$ & $\begin{array}{l}\text { MC - Male condom. } \\
\text { FC - Female condom. } \\
\text { TOP - Termination of } p\end{array}$ & nancy. & $\begin{array}{l}\text { - Diaphragm. } \\
\text { - Spontaneous miscarr } \\
\text { - Live child. }\end{array}$ & ge. \\
\hline
\end{tabular}

of their standard medical care. In addition, referrals may be made to a family planning clinic (FPC) held on the same site run by doctors experienced in both family planning and the care of patients with HIV disease. Ten HIV seropositive women attending the on site FPC were interviewed and the reasons for their contraceptive choice ascertained.

The women were aged 21-35 years and originated from Europe (5), Africa (3), South America (1) and the Caribbean (1). Two had advanced symptomatic HIV disease (Centres for Disease Control class IV, CDCIV). All had regular sexual partners of whom six were HIV seropositive and four were of unknown serostatus.

All women wished to continue with condoms as a barrier method of contraception and as protection against HIV transmission. Three women wished to continue with condoms alone but also wished to use the female condom (Femidom), including two women whose partners were having particular difficulty complying with the use of male condoms.

Seven were concerned about the risk of pregnancy and this was the main reason for requesting a second "double" contraceptive method additional to condoms. Six women chose hormonal contraception, two women the progestogen only contraceptive pill (POP), three women an injectable progesto- gen (IP), one woman the combined oral contraceptive pill (COCP). One woman chose to continue with an intrauterine contraceptive device (IUCD). Their contraceptive choice was based on previous experience and satisfaction with a method (2) or dissatisfaction and a desire to try a new method (8) (table).

An additional influencing factor in those choosing an injectable progestogen was the suppression of menstruation which was regarded as a reminder of their fertility and sorrow at their decision not to conceive. In this sub-group one woman later requested sterilisation, after separating from her partner, as she feared a second child with a different father might be separated from his sibling when she died.

It is essential that any additional contraception supplied does not facilitate the transmission of HIV, worsen immunosuppression, hasten the development of the acquired immunodeficiency syndrome (AIDS) or lead to the abandonment of condoms.

Contraceptive discussions must continue to promote the use of condoms and we routinely recommend the use of male condoms impregnated with nonoxynol-9 spermicide. However, in couples where male condoms are not being used the female condom under the woman's control may be an alternative, as in vitro data, albeit limited, have shown no HIV leakage across the polyurethane sheath. ${ }^{5}$ 
There appears to be no conclusive evidence to avoid hormonal contraception in HIV seropositive women. On balance, based on immune responses, ${ }^{6}$ it may be preferable to consider a progestogen-only pill or an injectable progestogen. An IUCD should be avoided in HIV seropositive women if possible, although we were unable to do so in one patient as all other methods were unacceptable.

We advocate that all HIV seropositive women should have easily accessible contraceptive advice. It is important to realise that although fear of pregnancy may be the prime reason for requesting a second contraceptive method other influences may be present.

E M CARLIN

J M RUSSELL

F C BOAG

St Stephen's Clinic,

Chelsea and Westminster Hospital,
London SW10 9NH, UK

Accepted for publication: 12 August 1994.

1 Van de Perre P, Jacobs D, Sprecher-Goldberger S. The latex condom, an efficient barrier against sexual transmission of AIDS-related viruses. AIDS 1987;1:49-52.

2 European Study Group on Heterosexual Transmission of HIV. Comparison of female to male and male to female transmission of HIV in 563 stable couples. BMF 1992; transmission

3 Saracco A, Musicco M, Nicolosi A, et al. Man-to-woman sexual transmission of HIV: longitudinal study of 343 sexual transmission of HIV: longitudinal study of 343 steady partn $497-502$.

4 Selwyn PA, Carter RJ, Schoenbaum EE, Robertson VJ, Klein RS, Rogers MF. Knowledge of HIV antibody status and decisions to continue or terminate pregnancy among intravenous drug users. $7 A M A$ 1989;261:3567-71.

5 Drew WL, Blair M, Miner RC, Conant M. Evaluation of the virus permeability of a new condom for women. Sex Transm Dis 1990;17:100-12.

6 Keller AJ, Irvine WJ, Jordan J, Loudon NB Phytohemagglutin-induced lymphocyte transformation in oral contraceptive users. Obstet Gynecol 1977;49: in ora

The use of barrier contraceptives in Denmark during the AIDS epidemic

In the absence of a cure or vaccine for AIDS, changing sexual behaviour remains the only strategy available to those, who are concerned with this aspect in public health campaigns. Since 1985 the Danish health authorities have given high priority to educational campaigns for prevention of HIV infection in the general population. As a way of controlling the spread of the infection this public information has focused on the use of barrier contraceptives especially condoms for casual sexual intercourse. Less emphasis has been put on reducing the risk of HIV infection by having fewer sexual partners.

Data from Denmark indicate a substantial reduction in the prevalence of major STDs, syphilis, gonorrhoea and hepatitis B since the mid-1980s. ${ }^{1}$ In a major STD clinic in Copenhagen a decrease was also noted in the prevalence of chlamydia infections, whereas no consistent changes were detectable in genital warts and genital herpes."

As a result one should expect a general increase in the use of condoms in Denmark since 1984. A figure of the total national use of condoms per year is for obvious reasons not available. In Denmark, the Medicines Department, National Board of Health approves all batches of sold condoms. Each batch contains 72,000 condoms or less. From 1984 to 1993 we have for each year collected the numbers of approved condoms in Denmark (table). The total number of accepted condoms presumably reflects the number of sold or handed out condoms. In addition the number of sanctioned diaphragms each year from 1984 to 1993 are shown in the table.

The table shows that a slight increase in the number of approved condoms occurred from 10-11 millions in 1984-85 to 13-14 millions in 1990-93. In one single year (1988) more than 19 million condoms were accepted for sale. A steady but substantial decrease was noticed in approved diaphragms.

Recently published data have indicated an increased use of condoms during the AIDS epidemic among Danish adolescents ${ }^{23}$ and among females attending an STD clinic. ${ }^{4}$ The same trend was detected among US college women. ${ }^{5}$ This combined with the fact that sexual behaviour among heterosexuals has not changed in recent years ${ }^{34}$ should as a consequence result in a marked increase in the number of sold condoms. Although increased use of condoms has taken place, consistent use of condoms is rarely seen. ${ }^{467}$

An explanation for the observed decrease in STDs in Denmark is probably complex. Several factors may contribute, such as reduced promiscuity among homosexual males, increased use of condoms in high-risk individuals (homosexual males and prostitutes) reduced sexual activity in some groups of heterosexuals and to a certain degree an increased use of condoms in the general population.

CARSTEN SAND PETERSEN
KAARE WEISMANN
Department of Dermatology,
Bispebjerg Hospital, Bispebjerg Bakke 23,
DK 2450 Copenhagen NV,
Denmark

Address correspondence to: Dr C S Petersen.

1 Weismann K, Sand Petersen C, Søndergaard J. Sexually ransmitted diseases in Denmark and in an STD clinic in Copenhen 1980-1991. Acta Dermato-Venereol (Stockh) 1993;77:313-4.

2 Wielandt HB. Have the AIDS campaigns changed the pattern of contraceptive usage among adolescents? Acta tern of contraceptive usage amon

3 Rasmussen KL, Knudsen HJH. School pupils knowledge of, need for and use of contraception before and after the AIDS-campaigns. Sexual activity and contraceptional habits. Ugeskr Laeg 1994;156:1447-51.

The total number of approved condoms and diaphragms in Denmark from 1984 to 1993

\begin{tabular}{lllllllllll}
\hline & 1984 & 1985 & 1986 & 1987 & 1988 & 1989 & 1990 & 1991 & 1992 & 1993 \\
\hline $\begin{array}{l}\text { Condoms } \times 10^{6} \\
\text { Diaphragms }\end{array}$ & $11 \cdot 4$ & $10 \cdot 8$ & $13 \cdot 5$ & $13 \cdot 6$ & $19 \cdot 3$ & $12 \cdot 7$ & $13 \cdot 1$ & $13 \cdot 0$ & $13 \cdot 0$ & $14 \cdot 7$ \\
\hline
\end{tabular}

